FEDERAL RESERVE BANK OF SAN FRANCISCO

WORKING PAPER SERIES

\title{
Dual Labor Markets and Business Cycles
}

\author{
David Cook \\ Hong Kong University of Science \& Technology \\ Hiromi Nosaka \\ Kansai University
}

September 2005

Working Paper 2006-36

http://www.frbsf.org/publications/economics/papers/2006/wp06-36bk.pdf

The views in this paper are solely the responsibility of the authors and should not be interpreted as reflecting the views of the Federal Reserve Bank of San Francisco or the Board of Governors of the Federal Reserve System. This paper was produced under the auspices for the Center for Pacific Basin Studies within the Economic Research Department of the Federal Reserve Bank of San Francisco. 


\title{
Dual Labor Markets and Business Cycles
}

\author{
David Cook* \\ Department of Economics \\ Hong Kong University of Science 85 Technology \\ Clear Water Bay, Kowloon, Hong Kong SAR
}

\author{
Hiromi Nosaka \\ Kansai University \\ Osaka, Japan
}

September 2005

\begin{abstract}
In this paper, we model a dynamic general equilibrium model of a small open developing economy. We model labor markets as including both formal and informal urban employment as well as rural employment. We find that modelling dual labor markets helps explain why output in developing economies may fall even as labor inputs remain constant during finanical crises. An external financial shock may lead to a reallocation of labor from productive formal sectors of the economy to less productive informal sectors.

Keywords: Bank balance sheet channel; Foreign currency debt; Sticky prices; Exchange rate depreciation
\end{abstract} JEL Classification: F3; F4

\footnotetext{
*E-mail: davcook@usthk.ust.hk Phone: (852) 23587614 Fax: (852) 2358 2084. David Cook gratefully acknowledges support from the Research Grants Council of Hong Kong (Project No. HKUST6213/00H).
} 


\section{Introduction}

At least since Lewis (1954) development economists have argued that labor markets in emerging markets are different. In particular, it might be argued that labor markets are segmented into parallel markets characterized by different levels of wages with some labor market imperfection preventing an equalization of wages in the dual markets. One characterization of these labor markets (due to Harris and Todaro, 1970) is of a split between rural and urban labor markets with urban wages being higher to compensate for the possibility of unemployment which occurs in cities but not in the countryside. A second characterization (due to Fields, 1975) is of a split between a formal urban economy using modern production techniques and an informal economy which consists of workers who work in low wage/productivity jobs while they seek positions in the formal economy. In this paper, we incorporate both characterizations of labor markets into a quantitative dynamic general equilibrium model of a small open economy (following Mendoza, 1991) in order to examine how these market imperfects affect the dynamic response to shocks.

We formulated a model in which their is both a frictionless rural sector and urban sector divided into formal and informal firms. A key element of our model is that there are search frictions in finding positions in the most productive formal firms. This friction is modeled as a matching technology between workers in the informal sector and firms in the formal sector along the lines of Mortenson and Pissarides (1999). We then think of the low-productivity frictionless informal sector as an employer of last resort for urban workers. Workers would prefer living in the rural sector but are willing to work in the informal urban sector because while in that sector they can search for other work and their is some probability that they may be matched to a high wage formal job. In equilibrium, workers are willing to remain in the agricultural sector because of the probability that they will have to remain in informal jobs in the urban sector.

We our interested in using this model to learn about the quantitative dynamics of the business cycle response of emerging markets to internal and external shocks. Our paper follows a number of papers including Andolfatto (1996), Merz (1995), which have used search models to understand the business cycle dynamics of unemployment in developed economies. However, our models of developing economy labor markets is distinct along

a number of dimensions. First, their is no unemployment in our model. All workers are 
always employed. However, some workers will be considered under-employed in the sense that they are employed in low productivity sectors. Second, this underemployment is the method for channeling workers from one sector of the economy to another. Changes in the relative prices of goods may cause sectoral switches which lead to increased levels of underemployment. Third, we assume that underemployed workers in the informal sector are producing non-traded goods. Changes in relative exchange rates will change the costs and benefits for searching for work in the most productive sector of the economy. Fourth, matched workers and firms in the formal sector bargain over wages. The share of wages paid to workers in that sector depends on the value of their alternative. In the developed economy models, the alternative is a fixed utility level determined by home production. The threat point in workers bargaining in our model is a function of the relative price of non-traded goods. Therefore, fluctuations in the real exchange rate will affect workers bargaining power. Fifth, we assume that firms in formal sector must accumulate a stock of managerial or organizational capital in order to post vacancies to hire workers. Firms cannot quickly adjust their hiring rate of workers in the formal sector.

We examine the behavior of our model in light of an empirical question. Researchers from RAND Family Life Surveys conducted studies of urban and rural households in Indonesia during the periods immediately preceding and immediately following the East Asian crisis. Thomas, Smith, Beegle, Teruel, and Frankenberg (2002) find that there was no decline in employment rates during the crisis which is surprising in the context of a large decline in output. Further, the real wages of both urban workers, both employees and self employed decline by more than $40 \%$. The real wages of employees in rural Indonesia also declined by more than $40 \%$. However, real wages of the self-employed in rural markets do not decline. Another study by the same group (Thomas, Beegle, and Frankenberg, 2000) shows that though overall employment stayed the same in Indonesia, there was a substantial rise in job churn during the crisis.

A number of papers have modeled the East Asian crisis as the result of an external interest rate shock including Christiano, Gust, and Roldos (2004), Cook and Devereux \{forthcoming), Gertler, Gilchrist and Natalucci (2003) and Mckibbin (1999). We ask two questions. First, how much of the decline in output and productivity that we observe in Indonesia can be explained as an equilibrium response to an external real interest shock of the size observed in East Asia in 1998. Second, how much of the decline in urban wages 
along with the differential between rural and urban wage outcomes can be explained as a response to an interest rate shock We find that in a dual labor market model based on search, in which average wages are calibrated to pre-crisis sectoral levels, a preponderant share of the decline in output can be explained by an interest rate shock. We also find that urban wages drop substantially by amounts comparable with the data and that a financial crisis results in a large narrowing of the wage gap between agricultural workers and urban workers.

Given the ability of the model to match several aspects of a developing economy financial crisis, we ask whether the transmission mechanism may have implications for the propagation of more standard business cycle shocks. In particular, we examine the behavior of the model in response to a shock to the formal sector of the economy in the context of thinking about China's experience with export led growth. China also has segmented labor markets; Brooks and Tao (2004) point out that in China the productivity of labor in urban areas is up to 6 times as large as in rural areas. In our model, technology shocks in the formal traded goods sector of the economy attracts workers to more productive urban areas. This generates a production multiplier that causes a much larger increase in productivity than can be accounted for by the direct effects of the shock. By contrast, an increase in productivity in the formal non-traded sector will crowd workers out of informal urban markets resulting in an actual contraction in output.

A large literature has studied labor markets in developing economy in the context of formal and informal employment (see Fields, 2005, for a review). Agenor and Aizenman, 1994, pioneer the study of segmented developing economy labor markets in macroeconomic models. Agenor, Fernandes, Haddad, and van der Mensbrugghe (2003), build a large multisectoral model to study the impact of macroeconomic shocks on poverty and income distribution. Agenor (2005) also considers some of the analytical implications in segmented labor markets motivated by efficiency wage setting or minimum wage laws. By contrast, our goal is to integrate a search based model of labor markets in a developing economy rational expectations dynamic general equilibrium framework. Laing, Park, and Wang, (2004) model search in China's urban sector to develop a model of segmented wages. King and Welling (1995) and Coulson, Laing, and Wang (2001) construct search models with unemployment in multiple location. 


\section{Model}

\subsection{Environment}

There are three types of goods: agricultural goods designated denoted sector $A$, industrial goods denoted sector $T$, and non-traded goods denoted NT. Agricultural goods and industrial goods are internationally traded. Nontraded goods can be produced either in a formal sector designated $S$ or an informal sector, $U$. The industrial sector is also deemed a formal sector. Workers can work in any sectors with zero moving costs. In the agricultural sector and the informal non-traded goods sector, there are no search frictions in finding jobs. On the other hand, the workers are employed by firms and it takes time to find jobs in the formal sectors. We define $Y^{f}, K^{f}, N^{f}$, and $z^{f}$ are output, capital, labor input, and technology level for sector $f=A, T, S$, and $U$. We assume that $\ln z_{a}$ and $\ln z_{m}$ follow $\mathrm{AR}(1)$ processes.

\subsection{Agriculture Area}

The agriculture of the agriculture sector is a function of fixed land and labor:

$$
Y_{t}^{A}=L N D^{\nu_{A}}\left(N_{t}^{A}\right)^{1-\nu_{A}}
$$

Profits in the agriculture sector are Each worker is self-employed, and he chooses capital to maximizes his income of $w_{a}$.

$$
\Pi_{t}^{A}=\max _{L N D, N} P_{t}^{A} L N D^{\nu_{A}}\left(N_{t}^{A}\right)^{1-\nu_{A}}-w_{t}^{A} N_{t}^{A}
$$

where $P_{t}^{A}$ is the price of the agriculture good. The first order condition is,

$$
w_{t}^{A}=\left(1-\nu_{A}\right) P_{t}^{A}\left(\frac{L N D}{N_{t}^{A}}\right)^{\nu_{A}}
$$

Define profits in the agriculture sector as

$$
\Pi_{t}^{A} \equiv R_{t}^{A} \cdot L N D \quad R_{t}^{A} \equiv \nu_{A} P_{t}^{A}\left(\frac{L N D}{N_{t}^{A}}\right)^{-\nu_{A}}
$$

\subsection{Urban Area}

\subsubsection{Production}


The formal traded, numeraire goods sector is constant returns to scale and Cobb-Douglas in capital and labor.

$$
Y_{t}^{T}=z_{t}^{T}\left(K_{t}^{T}\right)^{\nu_{T}}\left(N_{t}^{T}\right)^{1-\nu_{T}}
$$

The formal nontraded goods sector is also Cobb-Douglas in capital and labor.

$$
Y_{t}^{S}=z_{t}^{S}\left(K_{t}^{S}\right)^{\nu_{S}}\left(N_{t}^{S}\right)^{1-\nu_{S}}
$$

Each formal firm in the formal traded or non-traded sector $f=S, T$ employs at most one worker, and the firm choose the capital input to maximize the flow profit. The first order condition which determines the optimal capital is:

$$
\left(\nu_{f}\right) P_{t}^{f} z_{t}^{f}\left(\frac{K_{t}^{f}}{N_{t}^{f}}\right)^{\nu_{f}}=R_{t}^{f} .
$$

Then, the flow revenue of the firms net of capital costs is:

$$
\pi_{t}^{f}=\left(1-\nu_{f}\right) P_{t}^{f} z_{t}^{f}\left(\frac{K_{t}^{f}}{N_{t}^{f}}\right)^{\nu_{f}}
$$

Each worker in the informal sector produces $b$ nontraded goods. Therefore, the quantity of nontraded goods produced is

$$
Y_{t}^{N T}=Y_{t}^{S}+b \cdot N_{t}^{U}
$$

\subsubsection{Employment}

In the urban labor market, there are workers employed in informal sector who seek jobs in the formal sector, $N_{t}^{U}$. Firms in each formal sector post vacancies $v_{t}^{f}$, respectively for a total number of .vacancies, $v_{t}=v_{t}^{T}+v_{t}^{S}$ Define labor market tightness, $\theta_{t}=\frac{v_{t}}{N U_{t}}$ - We assume search frictions in the labor markets in the formal sector. Their is some matching process between firms and potential workers in urban labor markets. The number of matched pairs is produced by a Cobb-Douglas constant-returns-to-scale function of $m\left(u_{t}, v_{t}\right)=M \times v_{t}^{\chi} u_{t}^{1-\chi}$. The probability that firms will be matched with a worker is $\frac{m}{v}=m(\theta, 1) \equiv q(\theta)$. The probability that informal sector workers find a job is $\frac{m}{N U}=$ $q(\theta) \cdot \theta$. The probability that any given match will be with a firm in sector $f$ is equal to the proportion of vacancies in that sector $\frac{v_{t}^{f}}{v_{t}}$. 
In each period their is a probability, $\sigma$, that matched pairs will disintegrate. Employment dynamics in each sector are

$$
N_{t+1}^{f}=q\left(\theta_{t}\right) v_{t}^{f}+(1-\sigma) N_{t}^{f},
$$

The workers are initially employed in the informal sector when they move to the urban areas. The wage in the informal sector is the marginal product of labor in that sector, $P_{t}^{N T} \cdot b$. Since they become employed in each formal sector with probability $q\left(\theta_{t}^{f}\right) \theta_{t} \frac{v_{t}^{f}}{v_{t}}$ the values to workers of being employed in the informal sector (denoted as $Q^{U}$ ) and each formal sector (denoted as $Q^{f}, f=S, T$ ) are,

$$
\begin{aligned}
Q_{t}^{U} & =P_{t}^{N T} \cdot b+E_{t}\left[\Theta_{t+1}\left(\sum_{f=T, N T}\left\{q\left(\theta_{t}\right) \theta_{t} \frac{v_{t}^{f}}{v_{t}}\left(Q_{t+1}^{f}-Q_{t+1}^{U}\right)\right\}+Q_{t+1}^{U}\right)\right], \\
Q_{t}^{f} & =w_{t}^{f}+E_{t}\left[\Theta_{t+1}\left(Q_{t+1}^{f}-\sigma\left(Q_{t+1}^{f}-Q_{t+1}^{U}\right)\right)\right],
\end{aligned}
$$

where $\Theta_{t+1}$ is the stochastic discount factor.

On the part of the firms, the vacant firms need to use a certain amount of managerial services, $h r_{t}$, to post vacancies. These services are produced with managerial capital, $h r_{t}=\frac{1}{c_{v}} \cdot K V_{t}^{f}$ which can be rented at competitive rate, $R V_{t}^{f}$. Since they can find workers with probability $q(\theta)$, the values of vacant firms $(V)$ and filled firms $(J)$ in each formal sector are

$$
\begin{aligned}
V_{t}^{f} & =-R V_{t}^{f} \cdot c_{v}+E_{t}\left[\Theta_{t+1}\left(q\left(\theta_{t}^{f}\right) \frac{v_{t}^{f}}{v_{t}}\left(J_{t+1}^{f}-V_{t+1}^{f}\right)+V_{t+1}^{f}\right)\right], \\
J_{t}^{f} & =\pi_{t}^{f}-w_{t}^{f}+E_{t}\left[\Theta_{t+1}\left(J_{t+1}^{f}-\sigma\left(J_{t+1}^{f}-V_{t+1}^{f}\right)\right)\right] .
\end{aligned}
$$

The free entry condition implies $V=0$. That leads to,

$$
R V_{t}^{f} \cdot c_{v}=q\left(\theta_{t}\right) E_{t}\left[\Theta_{t+1} J_{t+1}^{f}\right],
$$

If we assume the Nash bargaining solution, we have $\phi J_{t}^{f}=(1-\phi)\left(Q_{t}^{f}-Q_{t}^{U}\right)$ where $\phi$ is the bargaining power of the workers. By (1) and (5) with the formula of the Nash 
bargaining solution, we have

$$
\begin{aligned}
Q_{t}^{U}-E_{t}\left[\Omega_{t+1} Q_{t+1}^{U}\right] & =P_{t}^{N T} \cdot b+E_{t}\left[\Theta_{t+1} q\left(\theta_{t}\right) \theta_{t} \sum_{f=T, N T} \frac{v_{t}^{f}}{v_{t}}\left(Q_{t+1}^{f}-Q_{t+1}^{U}\right)\right], \\
& =P_{t}^{N T} \cdot b+q\left(\theta_{t}\right) \theta_{t} \frac{\phi}{1-\phi} E_{t}\left[\Theta_{t+1} \sum_{f=T, N T} \frac{v_{t}^{f}}{v_{t}} J_{t+1}^{f}\right] \\
& =P_{t}^{N T} \cdot b+\theta_{t} \frac{c_{v} \phi}{1-\phi} \sum_{f=T, S} \frac{v_{t}^{f}}{v_{t}} R V_{t}^{f} .
\end{aligned}
$$

By combining (2), (4), and (6) with the Nash solution, we have the formula for the wage rate.

$$
w_{t}^{f}=\phi \pi_{t}^{f}+(1-\phi) P_{t}^{N T} \cdot b+\phi \theta_{t} c_{v} \sum_{f=T, S} \frac{v_{t}^{f}}{v_{t}} R V_{t}^{f} . .
$$

\subsection{Migration}

We assume that people have some utility differential from living in the country side, GA. Depending on preferences GA could be positive or negative. The value for staying in this agricultural sector is,

$$
Q_{t}^{A}=w_{a}+E\left[\Omega_{t+1}\left\{\max Q_{t+1}^{A}+G A ., Q_{t+1}^{U}\right\}\right]
$$

When people can freely migrate, we need $Q_{t}^{U}=Q_{t}^{A}+G A$.. From (??) and (6),

$$
w_{t}^{A}=\left(P_{t}^{N T} \cdot b-G A\right)+\theta_{t} \frac{c_{v} \phi}{1-\phi} \sum_{f=T, S} \frac{v_{t}^{f}}{v_{t}} R V_{t}^{f} .
$$

By comparing (8) and (9), we have

$$
w_{t}^{f}=\phi \pi_{t}^{f}+(1-\phi)\left[w_{t}^{A}+G A\right] .
$$

\subsection{Households}

The household gets utility from the consumption which is a CES aggregate of consumption of urban goods denoted type $G$ and agricultural goods. Urban goods are a CES aggregate of goods produced in the non-traded and the industrial sector. This urban aggregate can be used either for consumption or for investment.

Households accumulate physical and organizational capital which they rent to each formal sector. The household earns income from wages, capital and land rental in the 
agriculture sector. The household can buy or sell a risk free bond at an external interest rate. There are complete insurance markets. Then, the representative household chooses consumption, $C$, subject to a budget constraint and capital accumulation equations to maximize utility.

$$
\max E_{0} \sum_{t=0}^{+\infty} \beta^{t} \frac{C_{t}^{1-\frac{1}{\psi}}-1}{1-\frac{1}{\psi}}
$$

subject to:

$$
\begin{aligned}
& P_{t}^{A} C_{t}^{A}+P_{t}^{N T} A_{t}^{N T}+A_{t}^{T}+B_{t+1}= \\
& \sum_{f=T, N T}\left\{w_{t}^{f} N_{t}^{f}+R_{t}^{f} K_{t}^{f}+R V_{t}^{f} K V_{t}^{f}\right\}+P_{t}^{N T} b \cdot N_{t}^{U}+w_{t}^{A} L_{t}^{A}+R_{t}^{A} L N D+\left(1+r_{t-1}\right) B_{t} \quad: \\
& s, t . C_{t}=\left[a^{1-\phi}\left(C_{t}^{A}\right)^{\phi}+(1-a)^{1-\phi}\left(C_{t}^{G}\right)^{\phi}\right]: \quad\left[\omega_{t}\right] \\
& A_{t}^{G}=\left[d^{\phi-1}\left(A_{t}^{T}\right)^{\phi}+(1-d)^{\phi-1}\left(A_{t}^{N T}\right)^{\phi}\right]^{\frac{1}{\phi}}=C_{t}^{F}+\sum_{f=T, N T}\left\{I_{t}^{f}+I V_{t}^{f}\right\} \\
& K_{t+1}^{f}=(1-\delta) K_{t}^{f}+I_{t}^{f}-\frac{e K_{t}^{f}}{2}\left(\frac{I_{t}^{f}}{K_{t}^{f}}-\delta\right)^{2} \quad f=T, N T \quad\left[\Lambda_{t}^{f}\right] \\
& K V_{t+1}^{f}=\left(1-\delta_{V}\right) K V_{t}^{f}+I V_{t}^{f}-\frac{e^{v} K V_{t}^{f}}{2}\left(\frac{I V_{t}^{f}}{K V_{t}^{f}}-\delta_{V}\right)^{2} \quad f=T, N T \quad\left[\Gamma_{t}^{f}\right]
\end{aligned}
$$

Note that the shadow values of relaxing the budget constraint are in brackets.

The first order conditions are standard.

$$
\begin{aligned}
C_{t}^{-\frac{1}{\psi}} & =\omega_{t}, \quad C_{t}^{A}=\left(\frac{\Omega_{t} P_{t}^{A}}{\omega_{t}}\right)^{\frac{1}{\phi-1}} a C_{t} \quad C_{t}^{G}=\left(\frac{\eta_{t}}{\omega_{t}}\right)^{\frac{1}{\phi-1}}(1-a) C_{t} \\
A_{t}^{T} & =\left(\frac{\Omega_{t}}{\eta_{t}}\right)^{\frac{1}{\phi-1}} \cdot d \cdot A_{t}^{G} \quad C_{t}^{F}=\left(\frac{\Omega_{t} \cdot P_{t}^{N T}}{\eta_{t}}\right)^{\frac{1}{\phi-1}} \cdot(1-d) \cdot A_{t}^{G} \\
\eta_{t} & =\Lambda_{t}^{f}\left(1-e\left(\frac{I_{t}^{f}}{K_{t}^{f}}-\delta\right)\right)=\Gamma_{t}^{f}\left(1-e\left(\frac{I V_{t}^{f}}{K V_{t}^{f}}-\delta_{v}\right)\right) \\
\Omega_{t} \frac{1}{\beta} & =E_{t}\left[\beta \Omega_{t+1}\left(1+r_{t}\right)\right] \\
\Lambda_{t}^{f} \frac{1}{\beta} & =E_{t}\left[\Lambda_{t+1}^{f}\left\{1-\delta-\frac{e}{2}\left(\frac{I_{t}^{f}}{K_{t}^{f}}-\delta\right)^{2}+e \frac{I_{t}^{f}}{K_{t}^{f}}\left(\frac{I_{t}^{f}}{K_{t}^{f}}-\delta\right)\right\}+\Omega_{t+1} R_{t}^{f}\right] \quad f=T, N T \\
\Gamma_{t}^{f} \frac{1}{\beta} & =E_{t}\left[\Gamma_{t+1}^{f}\left\{1-\delta_{v}-\frac{e v}{2}\left(\frac{I V_{t}^{f}}{K V_{t}^{f}}-\delta_{v}\right)^{2}+e v \frac{I V_{t}^{f}}{K V_{t}^{f}}\left(\frac{I V_{t}^{f}}{K V_{t}^{f}}-\delta_{V}\right)\right\}+\Omega_{t+1} R_{t}^{f}\right] \quad f=T,
\end{aligned}
$$

This stochastic discount factor can be written as $\Theta_{t+1}=\beta \frac{\Omega_{t+1}}{\Omega_{t}}$. 


\subsection{Equilibrium}

The feasibility conditions for the economy are,

$$
\begin{aligned}
Y_{t}^{N T}= & A_{t}^{N T} \\
& c_{v} v_{t}^{f}=K V_{t}^{f} \\
1= & N_{t}^{A}+N_{t}^{T}+N_{t}^{S}+N_{t}^{U}
\end{aligned}
$$

The external interest rate is assumed to be an increasing function of external debt.

$$
1+r_{t}=\frac{x_{t}}{\beta}-\mu_{B} B O N D_{t-1}
$$

where $x_{t}$ is a stochastic external interest rate shock with a steady state value of 1 .

Define the variable $\Xi_{t}$ as the history of shocks up until time t. We define an equilibrium as a number of policy functions $B O N D_{t+1}\left(\Xi_{t}\right), I_{t}^{f}\left(\Xi_{t}\right), v_{t}^{f}\left(\Xi_{t}\right), N_{t}^{f}\left(\Xi_{t}\right), C_{r}^{f}\left(\Xi_{t}\right), A_{r}^{f}\left(\Xi_{t}\right)$ which maximize the objective function of the household and firms subject to some price functions $P_{t}^{f}\left(\Xi_{t}\right), R_{t}^{f}\left(\Xi_{t}\right), R V_{t}^{f}\left(\Xi_{t}\right), r\left(\Xi_{t}\right), W^{f}\left(\Xi_{t}\right)$ which clear all markets for sectors $f=$ $A, T, S, U, N T, G$ as appropriate.

\section{Calibration}

We are unable to solve this problem analytically. We linearize the first order and equilibrium conditions of the model to find a numerical solution. A number of the parameters of the model will be set using data from developed open economies. Following Mendoza [26], the annualized world real interest rate is set at $4 \%$, i.e. in steady state $1+r=1.01$. We calibrate the capital intensity parameter for each production technology at a level $\nu_{A}=v_{T}=v_{S}=.3$. This follows Sarel (1997) who finds that capital intensity for agriculture in the OECD countries is .275 and the capital intensity in the manufacturing is .305. Sarel also finds that there is some variation in non-traded goods sectors with some sectors being relatively capital intense (like finance or utilities) while other sectors (like construction or commerce) are relatively labor intense. As a baseline we assume symmetry between the capital intensity in formal traded and nontraded sectors.

Following, Backus, Kydland, and Kehoe [5], the average annualized depreciation rate of physical capital is $\delta=.025$. We assume the same depreciation rate for managerial 
capital as for physical capital $\delta_{V}=25$. A wide ran of parameters have been used to calibrate the adjustment costs of physical capital in open economy models. Following Baxter and Crucini, (1993) we initially set the elasticity of the investment to capital ratio with respect to Marginal q equal to 15 for physical and managerial capital in both sectors. However, this results in a response of physical capital investment to interest rate shocks which is far larger than that observed in the data. Ultimately we set the elasticity of investment with respect to marginal q to be 15 for managerial capital and to be 4 for physical capital. We assume an intertemporal elasticity of substitution for consumption equal to .2 .

We use data on the Indonesia to set some of the parameters. We set the parameter $d=.4$ as two traded goods sectors constitute approximately $40 \%$ of Indonesia's nonagricultural GDP during the period 1993-2004. We set the parameter $a=.75$ to match the fact that agricultural output represents between 16-20\% of Indonesia's GDP. Following Cook and Devereux (JMCB forthcoming), we set the elasticity of substitution between traded and non-traded goods, $\frac{1}{1-\phi}=\frac{2}{3}$. We normalize the relative price of agricultural and industrial traded goods to 1 . We set the technology level in the non-traded informal sector and the parameter $\mu_{B}$ so that at an external interest rate equal to $\frac{1}{\beta}$ the relative price of traded and non-traded goods is equal to 1.

We set some of the parameters of the model following Andolfatto (1996). In particular, the rate of job disappearance $\sigma=.15$ and vacancies share in the matching function is set at $\chi=.4$. National surveys conducted by Indonesia and reported by the ILO reports that approximately 30 to $40 \%$ of the urban job force is in the informal sector. This indicates that matching may be more costly and less effective than in developed economies. During the period 1990-1996, the average wage rate in the agricultural and fisheries sector was about half of the average wage level and about $\frac{1}{3}$ the level observed in the electricity, gas, and water sector. We calibrate the vacancy cost parameter $c_{V}$, the informal urban wage parameter $b$, the agricultural life preference parameter, $G A$, and the technology of the matching function, $M$ so that the flow cost of posting vacancies is small (i.e $3 \%$ of GDP), approximately $30 \%$ of the urban population is in the informal sector, wages in the agricultural sector are $50 \%$ of average wages and $33 \%$ of the wages in the urban formal sector. In the model, this calibration implies that $44 \%$ of the population works in agriculture in steady state. In Indonesia, during the period 1990-1996, the average is 
approximately half.

\section{Interest Rate Shocks}

We examine the response of the model to a real interest rate shock. We assume that the external shock to interest rates follows and $\operatorname{AR}(1)$ process: $x_{t}=(1-\rho)+\rho x_{t-1}+\epsilon_{t}$. Following Cook and Devereux, (JIE, forthcoming) we model the financial crisis as a 1 time shock to the external interest rate with $\rho=.95$ and $\epsilon_{0}=.0175$. This is consistent with the sudden imposition of a $7 \%$ annualized risk premium on lending to Indonesia.

In Figure 1, we show the response of a number of aggregate and sectoral variables to the real interest rate shock In Figure 2, we show the response of sectoral labor variables. The rise in interest rates leads to a decline in demand for consumption, $C_{t}$, and investment, $I_{t} \equiv I_{t}^{T}+I_{t}^{N T}$. The equilibrium decline in consumption (of about $10 \%$ below steady state) is milder than the decline in investment (of about $70 \%$ below steady state). Consumption and investment decline immediately. The decline in domestic demand translates into a decline in demand for non-traded goods, $Y_{t}^{N T}$. The relative price of non-traded goods, $P_{t}^{N T}$, declines. In panel $(\mathrm{G})$, we show the response of the real exchange rate to the shock. We define the real exchange rate as the price of traded goods relative to a fixed basket consumer price index,

$$
C P I_{t} \equiv \frac{C^{A}}{C^{A}+C^{U}} \cdot P_{t}^{A}+\frac{d C^{U}}{C^{A}+C^{U}} \cdot P_{t}^{N} \quad R E X_{t}=\frac{1}{C P I_{t}}
$$

where variables without time indices are measured at steady state level. The real exchange rate depreciates by about $5 \%$ in the period of the shock and then declines.

The relative price of non-traded goods is the wage rate in the informal sector. As this depreciates sharply, the cost of being in the search market rises sharply relative to working in the agricultural sector. Table 2, Figure A shows that the population working in the agricultural sector increases sharply, by about $25 \%$. The number of workers in the urban informal sector decreases by about 55\%. The initial response of the economy is a shift in production from a nontraded sector to a traded sector. Figure 1, Panels (E) and (F) show that production of traded goods (which includes both agricultural and industrial goods) increases briefly while the production of nontraded goods declines. We define GDP as a constant price index (using the steady state as the base year): $G D P_{t}=Y_{t}^{A}+Y_{t}^{N}+Y_{t}^{T}$. 
The initial response to the shock is for GDP to decline by approximately $5 \%$ as labor moves from a more productive sector to the less productive than average agricultural sector.

Over time, we observe that GDP declines even more to a trough about $10 \%$ below steady state. . This occurs as employment in the most productive formal urban sectors begins to fall. The decline occurs in both the traded sector whose price depreciates as well as the industrial sector which faces international demand for its good at a fixed price. The move from the urban informal sector to the agricultural sector makes it very hard for the formal firms to find matching employees. Further the intertemporal costs of managerial capital in the formal sector increases. Both of these reduce the labor in the formal sectors which are the most productive sectors of the economy.

Considering wages, we observe that real wages in the urban sector decline suddenly following the shock. We define real wages in the urban sector as $\frac{W_{t}}{C P I_{t}}$ where the wage rate measures the average wage rate

$$
W_{t} \equiv \frac{N U}{1-N A} P_{t}^{N} b+\frac{N T}{1-N A} w_{t}^{T}+\frac{N S}{1-N A} w_{t}^{S}
$$

First, the relative price level of the informal sector declines. Second, this sector is the alternative for workers in the formal sector. In their bargaining with firms, the threat point of workers declines and the wage share of workers also declines. Real wages in the agriculture sector decline as well but to a much lower degree. Under perfect labor markets, real wages should decline equally in all sectors.

It is worthwhile to compare the response of the model to the data as it appears in Indonesia during the late 1990's. In Figure 3, we show the response of some Indonesia macroeconomic aggregates to the East Asian crisis. We assume that macroeconomic shocks between July 1997 and December 1999 were dominated by the effects of the crisis. Prior to 1997, it may well be argued that the East Asian economy was experiencing a boom. Following Cook and Devereux (JMCB, forthcoming), we construct a forecast of GDP from the standpoint of the second quarter of 1997. We then treat the effects of the crisis as the deviation of the actual realizations from that forecast. Constant price quarterly NIPA data for Indonesia is available for the period 1993-2003. It will be difficult to calculate the trend growth rate with so little pre-crisis data. We get annual constant local currency unit data on GDP, personal consumption expenditure, gross fixed capital 
formation, exports and imports from the World Bank World Development Indicators. For each year between 1981 and 1993, we calculate annual growth rates which we allocate evenly to each of the quarters of a given year. We then use these growth rates along with the levels of the corresponding 1st quarter 1993 data to construct chain linked data for each quarter from 1993 to 2003. Indonesia switches to a new base year after 2003. We use the quarterly growth rates of the new official data to chain-link levels for the period 2004-2005. We estimate an AR(1) process with a linear quadratic trend using quarterly NIPA data as the forecasting model.

Our model captures several aspects of the data. First, we observe large and persistent declines in investment, and consumption. The decline in both investment and consumption are larger than those observed in the data though the decline in investment is larger than the decline in consumption as observed in the data. The dynamics of the decline in investment and consumption do not match those observed in the data. Investment in the model drops only with a lag in the data, but drops to its trough level in the period of the shock. It may be important to model investment adjustment costs as in Cook and Devereux (JIE, forthcoming). In the model, consumption drops sharply and persistently in the period of the shock. In the data, consumption actually rises sharply in late 1997 before falling sharply in 1998. However, the measured decline in personal consumption expenditure is very short-lived. In both the model and the data there is a persistent improvement in the trade balance. However, the improvement is much sharper in the model than in the data. This reflects the larger declines in consumption and investment observed in the model than in the data. The real exchange rate depreciation that we observe in the data is far larger than we observe in the model. The lack of modelling of any nominal rigidities may explain this gap.

The decline in Indonesian GDP that occurs in the data is of approximately the same size as in the model. In both cases, the decline in output occurs with a lag. The trough effect on GDP of the data is approximately reached by mid-1998. We also examine annual data on workers per sector. We model the effect of the crisis on agricultural workers as a share of the total workforce as the deviation from the pre-crisis trend. Workers do indeed return to agricultural employment at the time of the East Asian crisis. Interestingly, this increase seems to be comparable in size with that observed in the model. 


\section{Technology Shocks}

First, we examine the response of the economy to a permanent shock to technology in the traded sector. We assume that technology follows a process $z_{t}^{T}=z_{t-1}^{T}+\epsilon_{t}^{T}$. Figure 4 and Figure 5 show the response to a a realization of $\epsilon_{0}^{T}=.01$. The direct impact of the shock is to increase output in the formal traded goods sector. The indirect effect would be to attract workers to the urban sector. The high traded goods productivity level leads to a rise in the relative price of non-traded goods. This offers rural sector workers an immediate incentive to move to the urban sector. The greater prospects of a job in the industrial sector also attracts workers to the urban sector. The movement of workers from the low wage rural sector to the city increases overall productivity. A $1 \%$ increase in technology in a sector that makes up $\frac{1}{3}$ of the economy leads to an overall rise in GDP of nearly $1 \%$. As the workers in the informal sector find jobs in the industrial sector GDP grows by even more over time reaching a permanent peak increase of GDP of $2 \%$ above steady-state. . The initial effect of the shock will be for agricultural goods production to decline, so there is an initial decline in overall traded goods production. The nontraded sector expands as agricultural workers move into the informal traded goods sector. Wages in the urban sector rise immediately both because of the increase in productivity in the industrial sector and the increase in the relative price of the non-traded good. The real exchange rate appreciation directly increases the wages of nontraded sector workers but also increases the bargaining power of formal sector workers. The real wages of agricultural workers wages rise more mildly and more slowly.

Second, we examine the impact of a positive realization, $\epsilon_{0}^{S}=.01$, of random walk nontraded technology, $z_{t}^{S}=z_{t-1}^{S}+\epsilon_{t}^{S}$. The direct impact of this shock will be to increase the productivity of workers in the non-traded sector. The indirect impact will be a real depreciation which will crowd workers out of the informal urban sector and into the rural economy. Surprisingly, the indirect effect is stronger. The decline in urban employment reduces GDP by a very small amount in the short run, but in the long-run the lack of available employment matches leads to a contraction in the level industrial production. This reduces overall consumption and investment. The shift of the workforce from the informal non-traded sector to the agricultural sector increases traded goods production but reduces non-traded goods production. 


\section{Conclusion}

In our paper, we find that sectoral reallocation can account for much of the quantity and dynamics of output and productivity in Indonesia during the East Asian crisis if this is modelled as a sharp and persistent rise in external interest rates. An external shock induces a migration of labor to the low productivity agricultural sector. Due to a search matching process in the urban sector, the sectoral shift grows more significant over time as workers leave the highest productivity formal sectors. We find that in our model, an interest rate shock leads to a narrowing of the wage differential between agricultural and urban workers and a large decline in overall real wages. The depreciation of the value of urban informal workers ultimately leads to a shift of workers out of the high wage formal sector. However, the decline in wages that we observe is still smaller than the decline in wages that was observed by researchers in Indonesia. . This is an interesting contrast with some recent work in developed markets such as Shimer (2004) or Hall (2005) which suggests that search-matching models allow for too large a variation in real wages relative to the data.

Some standard changes in business cycle modeling may allow the model to deliver a decline in output more similar to that observed in the data. In this model, capital utilization is fixed. Therefore capital services decline only in the very long run. However, Gertler, Gilchrist and Natalucci (2003) and Meza and Quentin (2005) have argued that the decline in factor utilization was an important part of the decline in labor productivity levels during emerging market financial crises. Further, we have assumed a constant job separation rate. Endogenous job separation along the lines described in Mortenson and Pissarides (1994) or den Haan, Ramey, and Watson (1999). Perhaps if formal sector job destruction responds to shocks, changes in productivity levels might be sharper during a financial crisis. Also we have ignored impacts of the financial crisis that may directly impact formal sector firms. Neumeyer and Perri (2004) emphasize the importance of credit constraints on hiring workers in emerging markets which may more directly effect formal sector firms than the frequently self-employed informal sector workers. Sticky prices may also play a particularly important role for formally produced goods introducing a role for monetary policy.

Finally, our model is based on very slow matching between formal firms and informal 
sector workers. Only such slow matching would support such a large population in the informal sector at very low wages. This is much slower than the matching that occurs in developed economies. We model this as an exogenous parameterization of the matching technology. However, it may be important to endogenize this by assuming a lower level of skills or a more narrow level of formal education creating additional matching costs. Shifts in the skill base from the urban sector to the rural sector or vice versa may affect the dynamics of financial crises or business cycle shocks. 


\section{References}

[1] Agenor, P-R. and J. Aizenman, 1994, "Macroeconomic Adjustment with Segmented Labor Markets," NBER Working Paper 4769

[2] Agenor, P-R and R. Fernandes, Eduardo Haddad, and Dominque van der Mensbrugghe, 2003, "Analyzing the Impact of Adjustment Policies on the Poor: An IMMPA Framework for Brazil" Mimieo World Bank.

[3] Agenor, P-R., 2005, "The Analytics of Segmented Labor Markets," Mimeo. Manchester University.

[4] Andolfatto, David, 1996, "Business Cycles and Labor Market Search," The American Economic Review 86. p. 112-20.

[5] Backus, D.K., Kehoe, P.J.; Kydland, F.E. "International Real Business Cycles," Journal of Political Economy; 100(4), August 1992, pages 745-75.

[6] Baxter, M. and Crucini, M.J., 1993, "Explaining Saving-Investment Correlations," American Economic Review 83, 416-36.

[7] Brooks, R. and Tao, R., 2004, "China's Labor Market Performance and Challenges," China and the World Economy 12, p. 21-35.

[8] Correia, Isabel; Neves, Joao C.; Rebelo, Sergio "Business Cycles in a Small Open Economy," European Economic Review; 39(6), June 1995, pages 1089-1113.

[9] Coulson,N.E., Laing,D., and Wang,P. "Spatial Mismatch in Search Equilibrium" Journal of Labor Economics. October 2001; 19(4): 949-72.

[10] L.J. Christiano, C.Gust, J. Roldos, 2004, "Monetary policy in a financial crisis," Journal of Economic Theory 119, 64-103.

[11] Cook, D., and M.B. Devereux, 2004, Accounting for the East Asian crisis: A model of capital outflows in small open economies. Journal of Money, Credit, and Banking, Forthcoming. . 
[12] Cook, D. and M.B. Devereux, 2005,External Currency Pricing and the East Asian Crisis Journal of International Economics; Forthcoming

[13] den Haan, W.J. G. Ramey, and J. Watson, 2000, "Job Destruction and the Propagation of Shocks," American Economic Review 90, 482-98.

[14] Fields, G.S. "Rural-Urban Migration, Urban Unemployment and Underemployment, and Job Search Activities in LDCs", Journal of Development Economics 2, 168-88.

[15] Fields, G.S., 2005, "A Guide to Multisector Labor Market Models," World Bank Discussion Paper

[16] Takao Fukuchi, 2000, "Econometric Analysis of the Effects of Krismon Shocks on Indonesia's Industrial Subsectors," The Developing Economy pp. 490-517

[17] Harris, J. and M. Todaro, 1970, "Migration, Unemployment, and Development: A Two Sector Analysis," American Economic Review 40. 126-142

[18] Gertler, M., S. Gilchrist, and F. Natalucci (2001) "External constraints on monetary policy and the financial accelerator", mimeo, NYU.

[19] Greenwood, Jeremy; Hercowitz, Zvi; Huffman, Gregory W. "Investment, Capacity Utilization, and the Real Business Cycle," American Economic Review; 78(3), June 1988, pages 402-17.

[20] Hall, Robert E., 2005, "Wage Determination and Employment Fluctuations," American Economic Review

[21] Hansen, Gary "Indivisible Labor and the Business Cycle," Journal of Monetary Economics; 16(3), November 1985, pages 309-27.

[22] King, I and L. Welling, 1995, "Search, unemployment, and growth," Journal of Monetary Economics 35, 499-507.

[23] D. Laing, C. Park, and Wang,P. 2004, "A Modified Harris-Todaro Model of RuralUrban Migration For China"), in Collection in Honor of Gregory Chow, eds. (F. Kwan and E. Yu) eds. 
[24] Lewis, W.A., 1954, "Economic Development with Unlimited Supplies of Labor", , Manchester School

[25] McKibbin, Warrick J. (1999). "Modeling the crisis in Asia." in H.Hill and H.W. Arndt eds., "Southeast Asia's economic crisis: origins, lessons, and the way forward," Singapore: Institute of Southeast Asian Studies. Singapore.

[26] Mendoza, Enrique G. "Real Business Cycles in a Small Open Economy," American Economic Review; Volume 81, No. 4; September, 1991; pages 797-818.

[27] Merz, Monika, 1995, "Search in the Labor Market and the Real Business Cycle," Journal of Monetary Economics. November 1995; 36(2): 269-300.

[28] Meza, F and E. Quentin, 2005, :"Financial Crises and Total Factor Productivity," Mimeo.

[29] Mortensen, D. and C.A. Pissarides, 1999, "New Developments in Models of Search in the Search in the Labor Market," in HAndbook in Labor Economics, O. Asshenfelter and D. Card (eds.) Amsterdam

[30] Mortensen, D. and C.A. Pissarides, 1994, "Job Creation and Job Destruction in the Theory of Unemployment," Review of Economic Studies, 61, 397-415.

[31] Neumeyer, P.A., and F. Perri, "Business Cycles in Emerging Economies: The Role of Interest Rates" NBER Working Paper No. 10387

[32] Sarel, Michael, "Growth and Productivity in ASEAN Countries", 1997, IMF Working Paper

[33] Shimer, R., 2004, "The Cyclical Behavior of Equilibrium Unemployment and Vacancies," American Economic Review.

[34] Smith, J.P. and D. Thomas, E. Frankenberg, K.Beegle, and G. Teruel, 2002, "Wages, employment and economic shocks: Evidence from Indonesia", Journal of Population Economics, Volume 15,, Issue 1, Jan 2002, Pages 161 - 193 
[36] Thomas,D., K. Beegle, and E. Frankenberg, 2000, "Labor market transitions of men and women during an economic crisis: Evidence from Indonesia" Rand Working Paper. 

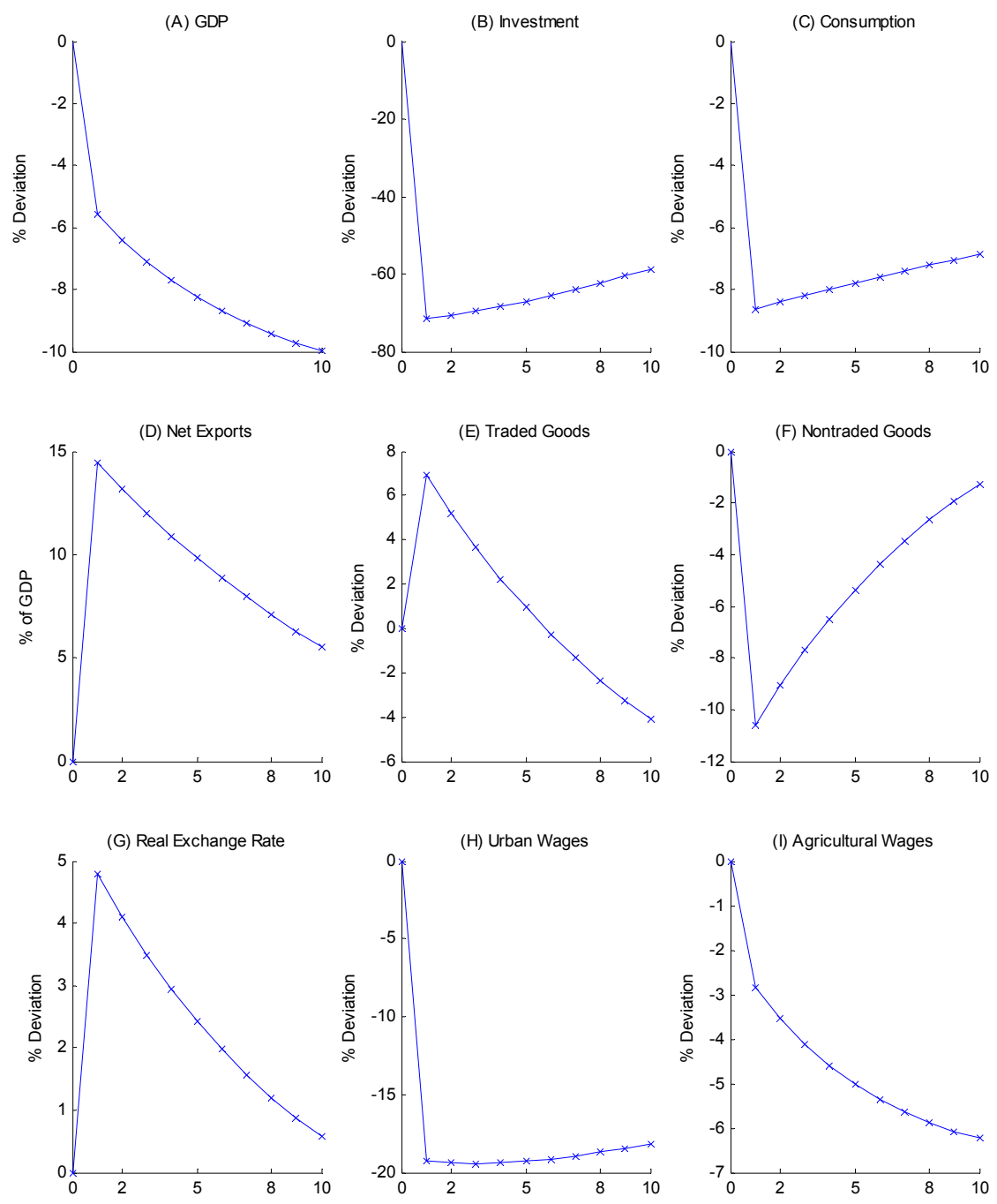

Figure 1: Response of Macroceonomic Aggregates in the Model to a 1.75\% External Interest Shock 

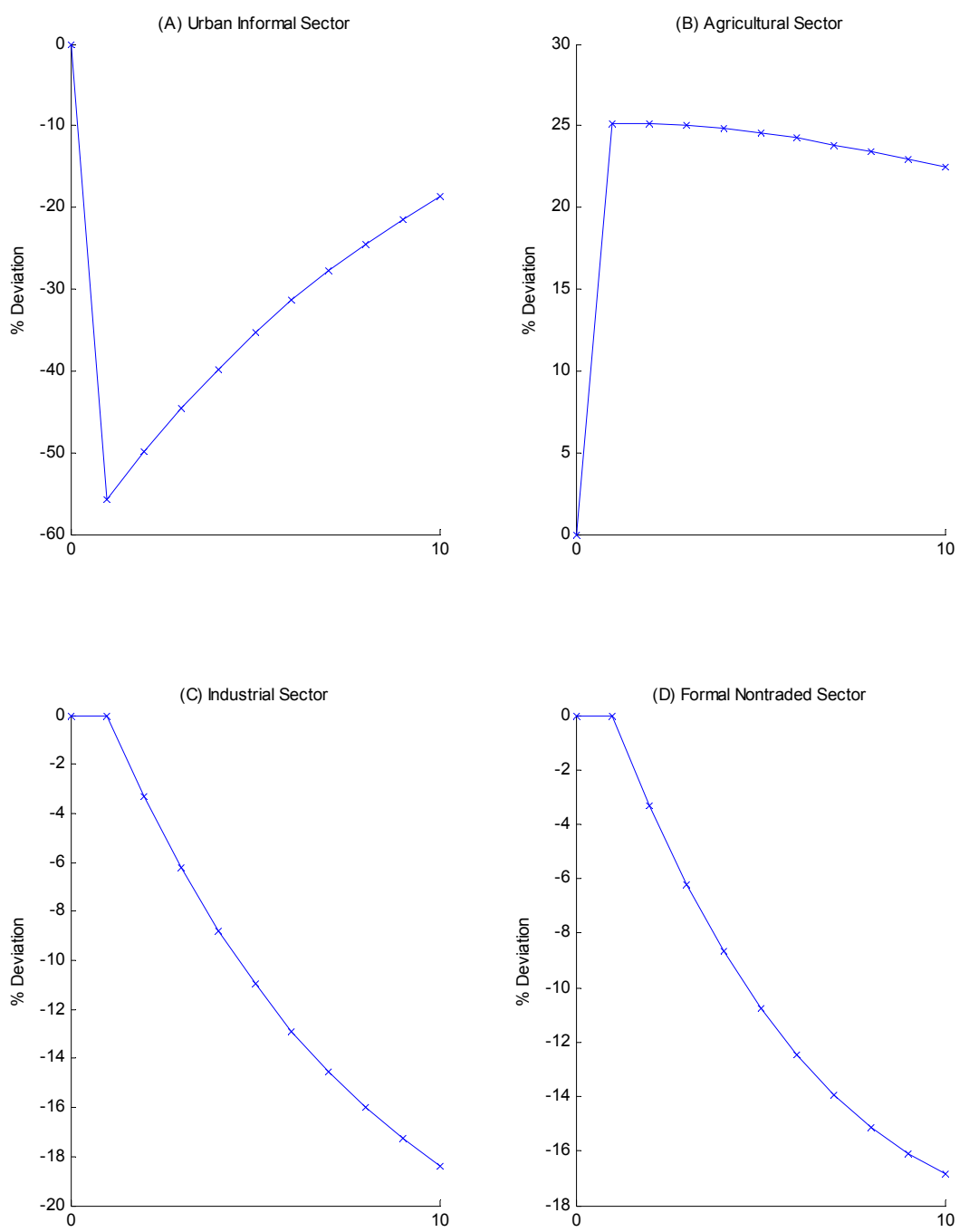

Figure 2: Response of Sectoral Labor to a 1.75\% External Interest Rate Shock 

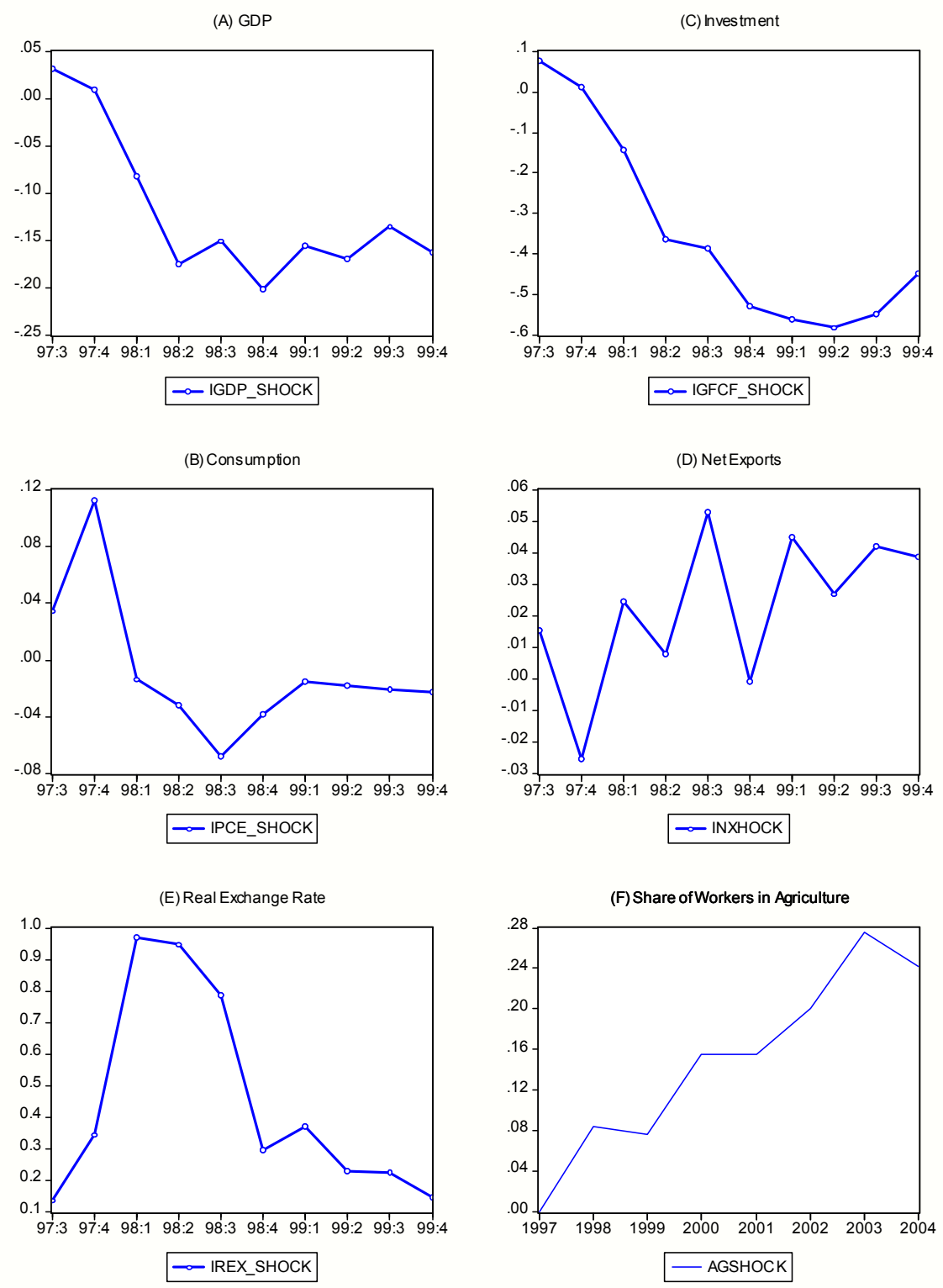

Figure 3: Response to the Asian Crisis in Indonesia 

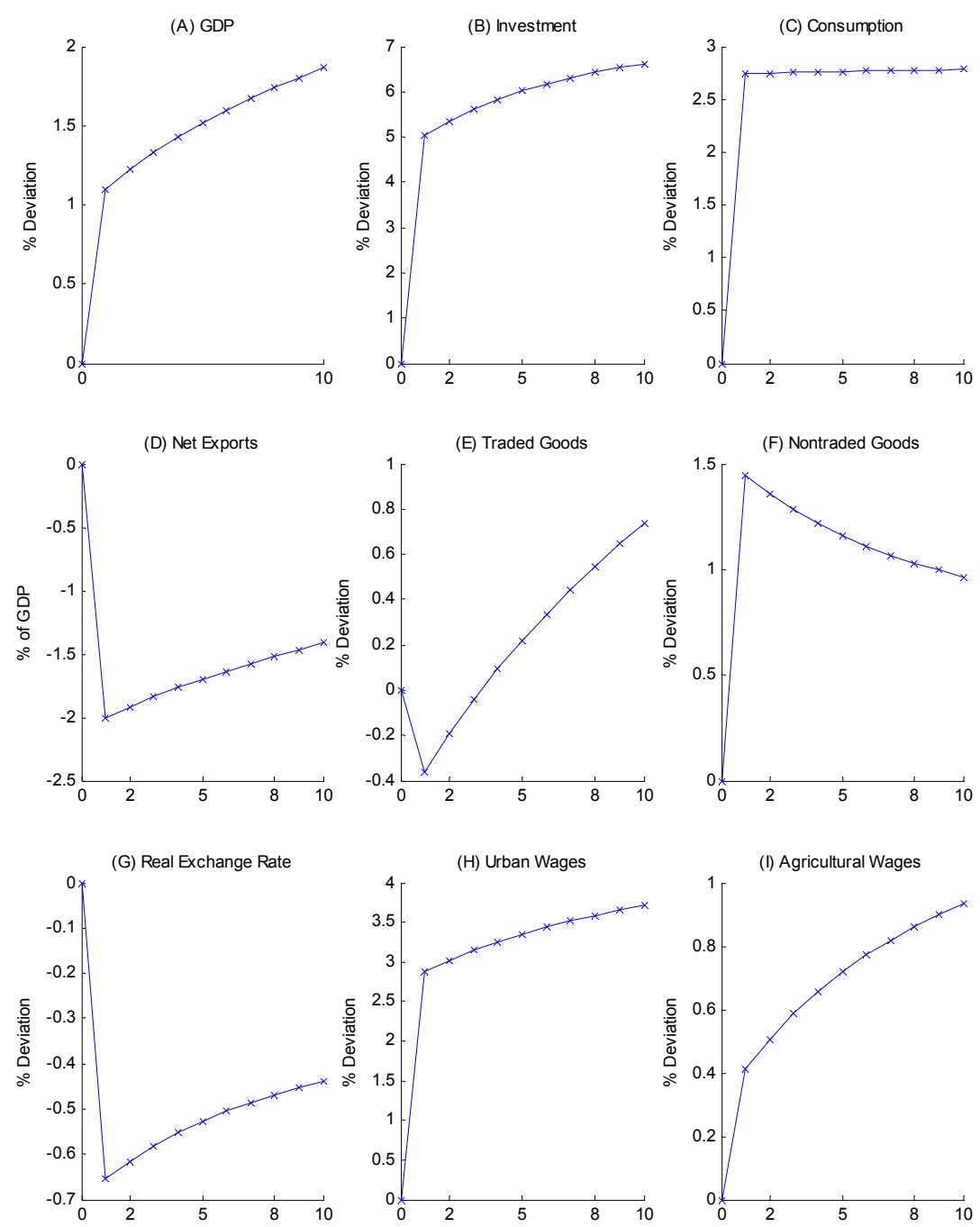

Figure 4: Response to a 1\% Technology Shock in the Formal Traded Goods Sector 

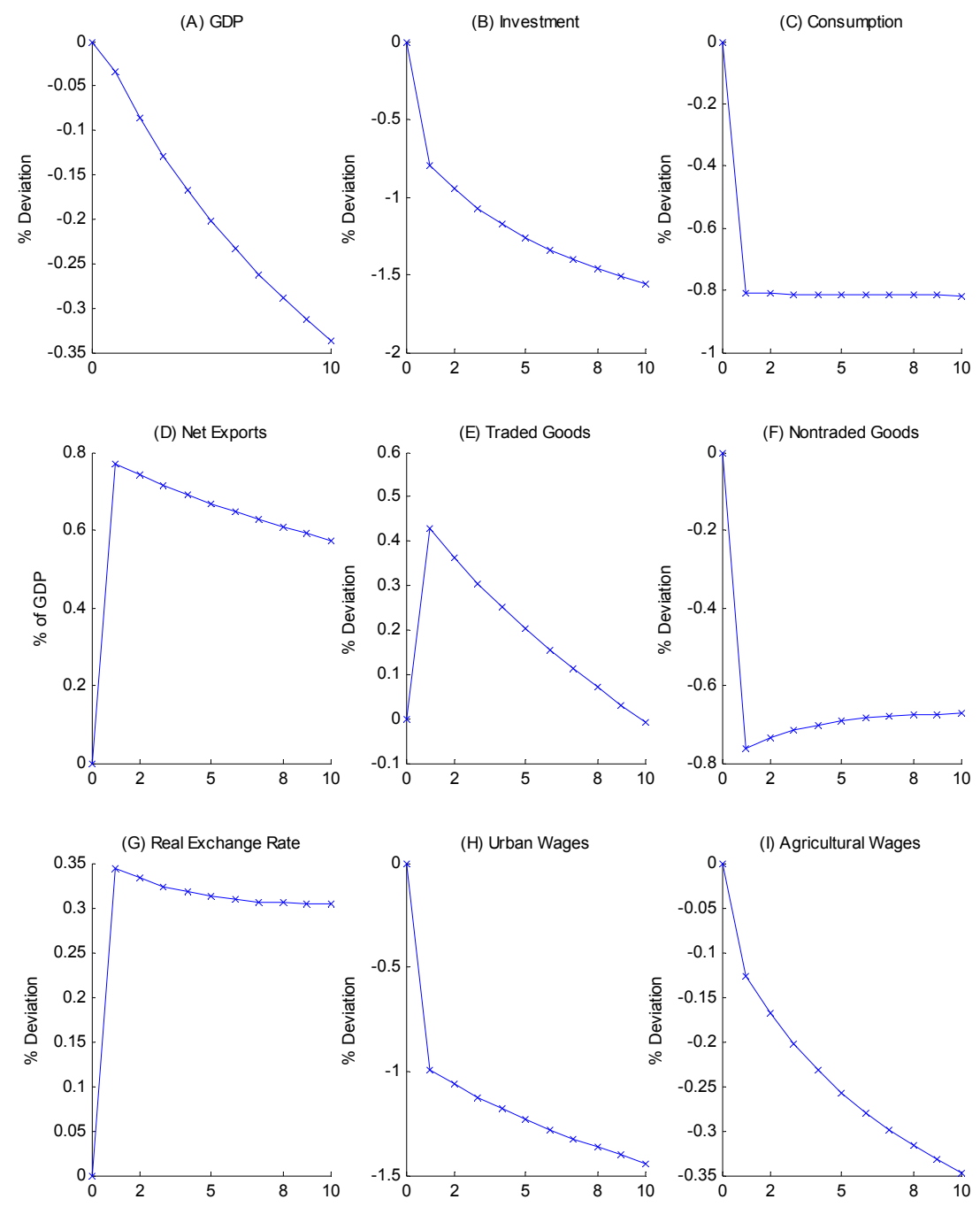

Figure 5: Response of Macroeconmic Aggregates to a 1\% Technology Shock in the Formal Nontraded Sector 